\title{
Evaluation of quality attributes of propranolol split tablets: focus on dose variability
}

\author{
Avaliação de parâmetros de qualidade de comprimidos divididos de \\ propranolol: foco na variabilidade de doses
}

Recebido em: 25/08/2017

Aceito em: $\quad 30 / 11 / 2017$
Jaqueline Kalleian Eserian; Márcia Lombardo

Centro de Medicamentos, Cosméticos e Saneantes. Instituto Adolfo Lutz. Avenida Doutor Arnaldo, 355, Prédio BQ, $5^{\circ}$ andar, Cerqueira César,

CEP 01246-902. São Paulo, SP, Brasil.E-mail: jkeserian@ial.sp.gov.br

\section{ABSTRACT}

Tablet splitting is a widespread practice among patients and health professionals aiming the administration of lower doses and the reduction of the cost of prescriptions. Nevertheless, potential concerns such as weight variation, stability and uneven drug content of the halves are related to this practice. The objective of this study was to evaluate the uniformity of half-tablets regarding weight and drug content in three different commercial products containing propranolol. Also, it was assessed drug content for whole tablets. Weight variation and drug content uniformity tests were evaluated for whole and split tablets, as well as the weight loss due to the splitting process. Drug content evaluation for whole tablets showed that all products were satisfactory. All the products were approved in the weight variation and drug content uniformity tests before splitting, with results close to $100 \%$, but the halves of all products failed the tests, presenting a high variability between the portions. In one of the products, halves ranged from 75.5 to $120.4 \%$ of the target drug content, indicating that when administered to patients, daily doses may vary around $45 \%$. Splitting propranolol tablets might compromise clinical treatment, affecting blood pressure and consequently producing side effects. Clinical implications due to tablet splitting might not be critical in some cases. Nevertheless, the high variability between doses should be considered by healthcare professionals when prescribing a therapy involving this practice.

Keywords: tablet splitting; uniformity of dosage; propranolol

\section{RESUMO}

A divisão de comprimidos é uma prática comum entre pacientes e profissionais da área de saúde visando à administração de doses mais baixas e redução do custo do tratamento. No entanto, problemas potenciais como variação no peso, estabilidade e distribuição desigual de substância ativa nas metades estão relacionados a esta prática. O objetivo deste estudo foi avaliar a uniformidade de comprimidos divididos em relação ao peso e conteúdo de substância ativa em três medicamentos comerciais diferentes contendo propranolol. Também avaliou-se o teor dos comprimidos inteiros. A determinação de peso e uniformidade de conteúdo foram avaliadas tanto nos comprimidos inteiros quanto nas metades, assim como a perda de massa devido ao processo de divisão. O ensaio de teor dos comprimidos inteiros foi satisfatório para todos os medicamentos. Os ensaios de determinação de peso e uniformidade de conteúdo apresentaram resultados satisfatórios para todos os medicamentos antes do processo de divisão, com resultados próximos a $100 \%$, mas suas metades apresentaram resultados insatisfatórios, evidenciados pela alta variabilidade entre as mesmas. Em um dos medicamentos, as metades variaram de 75,5 a 120,4\% do conteúdo de substância ativa, indicando que, quando administradas aos pacientes, as doses podem variar cerca de $45 \%$. Dividir comprimidos de propranolol pode comprometer o tratamento clínico, afetando a pressão sanguínea e consequentemente produzindo efeitos adversos. Implicações clínicas devido à divisão de comprimidos podem não ser críticas em alguns casos, entretanto, a alta variabilidade entre as doses diárias deve ser levada em consideração por profissionais da saúde ao prescrever tratamentos que envolvam esta prática.

Palavras-chave: divisão de comprimidos; uniformidade de doses; propranolol. 


\section{INTRODUCTION}

Tablet splitting is a very common practice among patients and health professionals aiming the administration of lower doses and the reduction of the cost of prescriptions $(1,2)$. This practice has the objective of better adjusting the dosage and meeting the patient needs (3) through the administration of halves or quarters (4). A study conducted in Germany found that about $25 \%$ of the tablets are split, even the ones that are unscored or not allowed to be split $(1,5)$.

Tablet splitting provides dose flexibility for patients, considering inter-individual differences in dose requirements, since appropriate individual doses are often not available on the market $(1,6,7)$, especially in cases of dose adjustment for achieving the desired clinical effect or discontinuing drug treatment (8). Further, some drugs can be beneficial in different indications than the ones approved by the authorities; usually in such cases lower doses are required. Consequently tablet splitting is an essential step (1).

Although some advantages are identified for tablet splitting, potential concerns such as weight variation, stability and uneven drug content of the halves are related to this practice (2). Uneven splitting might result in the administration of wrong doses (9), which is especially relevant for narrow therapeutic index drugs and drugs with nonlinear pharmacokinetics (2). Besides, not all tablets are suitable for splitting, especially the ones with no break-mark. Enteric coated, sustained and controlled release medications are meant to be swallowed intact. The presence of the coating protects the active ingredient from degradation and toxicity by its uncontrolled release; when splitting a coated tablet, effectiveness is compromised and the risk of side effects is increased $(1,8,10)$.

Different techniques can be applied to obtain split portions of tablets, such as the use of the tablet-splitter device, kitchen knife, scissors and hand breaking. Studies show higher patient's adherence to treatments using tablet splitters due to the technique's ease $(2,11,12)$.

Propranolol is a non-selective beta-adrenergic blocker that inhibits the sympathetic nervous system, reducing the cardiac contractility and the blood pressure (13). Hypertension and angina pectoris are considered the major labeled indications of propranolol. Furthermore, the drug is useful in treating cardiac dysrhythmia (14), capillary hemangioma (15), essential tremor (16) and migraine prophylaxis (17).
Propranolol oral tablets are available in three concentrations (10 mg, $40 \mathrm{mg}$, and $80 \mathrm{mg}$ ); depending on the clinical condition the dosage may vary from 30 to $640 \mathrm{mg}$ /day divided throughout the day (18). Due to unavailability of different doses, propranolol tablets are commonly split by patients for dose adjustment and also for cost-saving (8).

Recent clinical studies have demonstrated new therapeutic indications with lower concentrations of propranolol, as in the treatment of infantile hemangiomas (19), burned patients (20), and posttraumatic stress disorder (21), although further research is required to confirm these findings.

Many studies determine dose uniformity of split tablets through weight variation; however, dose uniformity through weight variation presumes that the drug is entirely even through the tablet, which is not necessarily true. Drug content uniformity test is a more reliable measure of dose uniformity of the split halves (2).

The objective of this study was to evaluate the uniformity of half-tablets regarding weight and drug content in three different commercial products containing propranolol.

\section{MATERIAL AND METHODS}

The samples consisted of three different products containing propranolol tablets of $40 \mathrm{mg}$. Propranolol hydrochloride reference standard was donated from Instituto Nacional de Controle de Qualidade em Saúde (INCQS, Rio de Janeiro, Brazil). Methanol was purchased from Vetec/Sigma-Aldrich (Duque de Caxias, Brazil). Polyvinylidene fluoride PVDF $0.45 \mu \mathrm{m}$ membrane filters were purchased from Merck Millipore (Darmstadt, Germany).

Weight variation test. Propranolol tablets from three different suppliers were nominated as P1, P2, and P3. A representative sample of 20 tablets was taken from each supplier. The tablets were removed from original sealed packs, weighed individually (22) and split into two parts (Split A and Split B) using a tablet-splitter device in a controlled laboratory environment by one trained pharmacist to avoid inter-person variability. The tablet splitter used in this study consisted of upper and lower platforms connected by a hinge. The center of the top platform contained a razor blade that split the tablet in half when pressed onto the lower platform. The tablets were placed in the V-region of the splitter in the 
bottom platform, positioned in a way that the razor blade would cut within the scored groove.

The obtained portions were individually weighted. Weight measurements were performed with an analytical balance (Mettler Toledo, AL204, Switzerland). The split-portions were dispensed into individual pharmacy containers until further analysis.

Drug content evaluation. Twenty whole tablets were transferred to a mortar and grounded to a fine and homogeneous powder with a pestle. The equivalent to one tablet was transferred into volumetric flasks in duplicate and propranolol was quantified; the results were compared to the theoretical target drug content (22).

Content uniformity test. Ten whole tablets and the first 20 split halves used in the weight variation test were transferred into individual volumetric flasks, and propranolol was quantified; the results were compared to the target drug content for whole tablets and to the target drug content for half-tablets, defined as $50 \%$ of the theoretical target drug content.

Propranolol quantification. To each $100 \mathrm{~mL}$ flask, it was added $5 \mathrm{~mL}$ of hydrochloric acid $1 \%$. The flask was occasionally shaken until the complete disintegration of the tablet. Then it was added $70 \mathrm{~mL}$ of methanol, sonicated for 10 minutes and shaken mechanically for 20 minutes. In the end, the volume was adjusted with methanol, and the solution was mixed and filtered through a membrane filter with a $0.45 \mu \mathrm{m}$ pore size (22). An aliquot was diluted quantitatively with methanol to provide a solution containing $32 \mu \mathrm{g} / \mathrm{mL}$ of propranolol hydrochloride. A standard curve was obtained by preparing a stock solution of propranolol reference standard in methanol and diluting it in the same solvent to achieve the points $5,10,20,30$ and $40 \mu \mathrm{g} / \mathrm{mL}$. The absorbances of the sample solutions and the standard curve were determined at $290 \mathrm{~nm}$ in $1 \mathrm{~cm}$ cells in a UV-Visible spectrophotometer (Agilent 8453, Santa Clara, USA), using methanol as blank (22).
Criteria and statistical analysis. A specification range of $90-110 \%$ was followed for drug content evaluation, according to the Propranolol hydrochloride tablets monograph (22).

The criterion for assessing drug content in whole tablets was based on the acceptance value (AV) of the first 10 tablets $\leq 15 \%$. If the $\mathrm{AV}$ is $>15 \%, 20$ more tablets should be tested; requirements are fulfilled if the AV for the 30 tablets is $\leq 25 \%$ and no individual value is outside of the $\approx 75-125 \%$ range (22). The AV was also calculated for the halves for comparison of variation to the whole tablets. The number of split portions falling outside the ranges of $85-115 \%$ and $75-125 \%$ was calculated.

The relative standard deviation expressed as a percentage (\%RSD) was calculated for weight variation and drug content uniformity tests. The USP criterion for medication lots regarding whole tablets is RSD $<6 \%$ $(9,23)$; in this paper, this value was extended for halftablets, similarly to other studies (9,24-27).

Weight loss criterion was based on the Food and Drug Administration (FDA) recommendation, in which no split portion should present loss of mass $>3 \%$ (28).

\section{RESULTS AND DISCUSSION}

The tablets used in this study presented a breakmark on one side. However, there were no instructions about tablet splitting in the label or package leaflet. Small fragments were generated when tablets were split. These fragments were not used in the tests.

Drug content evaluation, drug content uniformity and weight variability of the tablet halves were evaluated, as well as the weight loss due to the splitting process, calculated as the difference between the weight of the intact tablet and the sum of the weight of its split portions.

Table 1 shows the weight variation of tablets before and after splitting. The data show that the weight variation increased when comparing split tablets to intact ones. 


\section{Initama}

Table 1. Weight variation of whole propranolol tablets and split portions.

\begin{tabular}{|c|c|c|c|c|}
\hline \multicolumn{2}{|c|}{ Weight $(\mathbf{m g})$} & & P1 & P3 \\
\hline & Average & 133.2 & 183.1 & 201.1 \\
\hline \multirow{2}{*}{ Whole tablet } & Range & $124.9-139.0$ & $175.6-190.4$ & $174.3-218.3$ \\
& \%RSD & 2.4 & 2.6 & 5.2 \\
\hline \multirow{2}{*}{ Split A } & Average & 67.7 & 92.3 & 97.8 \\
& Range & $59.1-74.5$ & $78.4-109.5$ & $83.8-115.1$ \\
\hline & \%RSD & 6.0 & 10.7 & 10.0 \\
\hline & Average & 64.9 & 87.9 & 101.9 \\
\hline
\end{tabular}

\%RSD: relative standard deviation expressed as a percentage. Propranolol tablets from supplier 1 (P1); supplier 2 (P2); supplier 3 (P3). Split portions were nominated as Split A and Split B.

Whole tablets of all products presented $\mathrm{RSD}<6 \%$, unlike their split halves that presented RSD values ranging from 6.0 to $11.4 \%$. Figure 1 shows the percentage target weight of the split portions for the three products, allowing visual evaluation of weight variability.

The UV absorption spectrum was obtained for propranolol identification (Figure 2). The propranolol spectrum showed absorption maximum at $290 \mathrm{~nm}$.

A standard curve $\left(\mathrm{R}^{2}=0.9995\right)$ was established to quantify drug content (Figure 3 ).

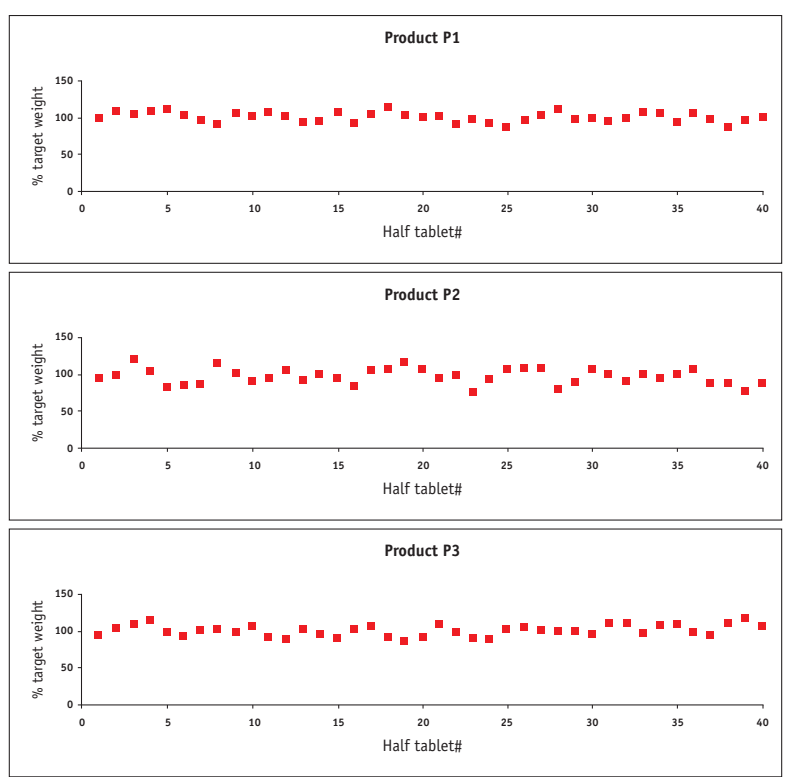

Figure 1. Percentage target weight of the portions from propranolol tablets. Halves distributed randomly for each product.

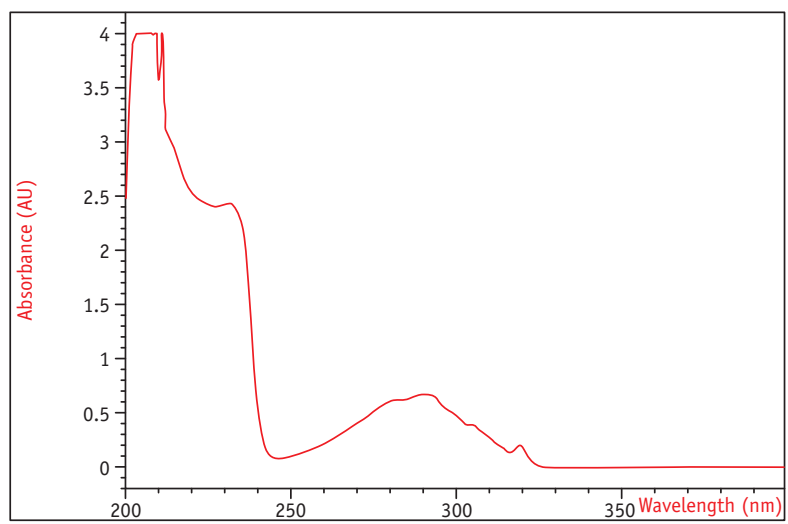

Figure 2. UV Spectrum of propranolol in methanol $(30 \mu \mathrm{g} / \mathrm{mL})$.

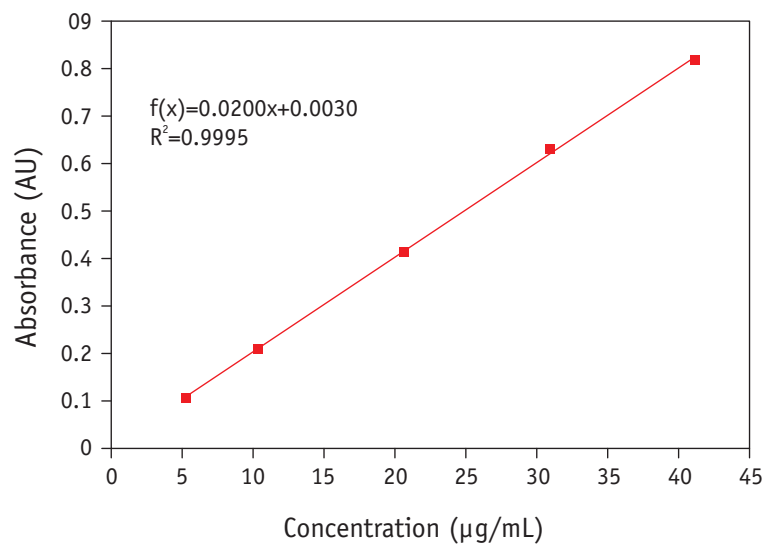

Figure 3. Propranolol hydrochloride standard curve $(5-40 \mu \mathrm{g} / \mathrm{mL})$.

Drug content evaluation showed that P1, P2, and P3 were within the range specification for propranolol 
tablets (90-110\%), presenting 97.7, 98.9 and $104.3 \%$, respectively.

A higher AV was observed in the content uniformity of the halves. All the products passed in the content uniformity test before splitting $(\mathrm{AV}<15 \%)$, with results close to the target (100\%), but the halves of all products failed the test (AV>15\%) (Table 2).

Table 2. Content uniformity of propranolol tablets before and after splitting (\%).

\begin{tabular}{|c|c|c|c|c|c|c|c|c|c|}
\hline \multirow{2}{*}{ Tablet \# } & \multicolumn{3}{|c|}{ P1 } & \multicolumn{3}{|c|}{ P2 } & \multicolumn{3}{|c|}{ P3 } \\
\hline & Tablet & Split A & Split B & Tablet & Split A & Split B & Tablet & Split A & Split B \\
\hline Average & 97.8 & 104.5 & 98.7 & 100.2 & 103.1 & 95.2 & 103.7 & 104.7 & 102.3 \\
\hline Range & $94.4-100.9$ & $92.6-109.4$ & $86.3-109.8$ & $98.0-101.8$ & $86.3-120.4$ & $75.5-112.2$ & 101.1-107.1 & $88.8-118.6$ & 83.7-116.7 \\
\hline RSD (\%) & 2.1 & 5.4 & 7.7 & 1.3 & 10.8 & 13.5 & 2.1 & 9.9 & 10.7 \\
\hline AV $(\%)$ & 5.6 & 16.7 & 18.1 & 3.1 & 28.3 & 34.1 & 7.5 & 28.2 & 27.1 \\
\hline
\end{tabular}

\%RSD: relative standard deviation expressed as a percentage. AV: acceptance value. Propranolol tablets from supplier 1 (P1); supplier 2 (P2); supplier 3 (P3). Split portions were nominated as Split A and Split B.

Table 3. Number of split portions of propranolol tablets falling outside the ranges of $85-115 \%$ and $75-125 \%$, presenting RSD $>6 \%$ and weight loss $>3 \%$.

\begin{tabular}{|c|c|c|c|c|}
\multirow{3}{*}{ Product } & \multicolumn{2}{|c|}{ Number of portions outside the range } & RSD $>6 \%(n=20)$ & $\begin{array}{c}\text { Tablets presenting weight loss }>3 \% \\
(\mathbf{n}=20)\end{array}$ \\
\cline { 2 - 5 } & $\mathbf{8 5 - 1 1 5 \% ( n = 2 0 )}$ & $\mathbf{7 5 - 1 2 5 \% ( n = 2 0 )}$ & Yes/No & $n$ \\
\hline P1 & $n(\%)$ & $n(\%)$ & Yes & 0 \\
P2 & $0(0)$ & $0(0)$ & Yes & 4 \\
P3 & $5(25)$ & $0(0)$ & Yes & 0 \\
\hline
\end{tabular}

\%RSD: relative standard deviation expressed as a percentage. Propranolol tablets from supplier 1 (P1); supplier 2 (P2); supplier 3 (P3).

Five halves and three halves were outside of 85 $115 \%$ range for products $\mathrm{P} 2$ and $\mathrm{P} 3$, respectively. $\mathrm{P} 2$ presented four tablets with weight loss $>3 \%$ (Table 3 ).

The most significant variation was observed in $\mathrm{P} 2$, which had tablet portions presenting a \%RSD value of $13.5 \%$. Drug content might have been affected by the weight variation and weight loss during tablet splitting. Since P2 had the greatest weight variation and weight loss, these results are in accordance.

A low variability in half-tablets weight and drug content is represented by a small RSD, indicating a high uniformity of the split portions. All whole tablets studied were within the specification for \%RSD for weight and content uniformity. However, all split halves were out of specification, except $\mathrm{P} 1$ portion $\mathrm{A}(5.4 \%)$.

To obtain lower doses than those available in the market, doctors usually prescribe half-tablets (9). Besides, tablets of the same medication with different concentrations cost the same or almost the same, what makes patients purchase highconcentrated tablets and split them, obtaining cheaper low-concentrated tablets (29).

Studies that determine the uniformity of divided tablets are important, since tablet-splitting is a common practice that should be safe to provide a proper clinical treatment for patients who need to split tablets (8).

Weight variation test showed that tablets did not split equally, which was evidenced by an increase in the \%RSD values for half-tablets in comparison to whole tablets.

Many studies aimed to investigate the weight uniformity of half-tablets. A study performed by Hill et al. (2009), evaluated warfarin sodium, simvastatin, metoprolol succinate, metoprolol tartrate, citalopram and lisinopril split tablets. The weight uniformity of split tablets was analyzed by comparing the weight of the half-portion to the theoretical half weight of the whole tablet using a proxy USP specification. They found that $33.3 \%$ of warfarin, $20 \%$ metoprolol succinate and $23.3 \%$ lisinopril split-tablets were out of specification, while the other medications were within the adopted range. As in our study, they also found that split portions of metoprolol succinate and lisinopril were outside the specification for $\% \operatorname{RSD}(7.7 \%$ and $8.13 \%$, respectively) (9).

Another study performed by Polli et al. (2003) found that 4 of 12 medications failed the weight uniformity test with a variation up to $20 \%$ of the theoretical half weight, according to an adapted USP Uniformity of Dosage Units criterion for whole tablets. They also pointed 
that split-tablets of lovastatin, lisinopril, rofecoxib, and simvastatin were out of \%RSD specification, with $\%$ RSD values ranging from 10.4 to $21.1 \%$ (30).

Studies have shown that drug content variation in split tablets is correlated to the weight variation resulted from the splitting process. However, the analysis of drug content has to be explored $(9,31)$.

According to a study performed by Zhao et al. (2010), splitting tablets equally by weight may not be satisfactory, once the intact tablet may not contain equal amounts of the drug in each half due to unequal distribution of the drug during manufacturing (5).

In accordance with the weight uniformity test, drug content analysis also showed evidence of uneven splitting in the present study. Comparison between half-tablet drug content and target drug content showed that 8 of 60 half-tablets $(13.3 \%)$ were outside of the specification range of $85-115 \%$. The most significant variation in half-tablet drug content was observed in $\mathrm{P} 2$, with halves ranging from $75.51 \%$ to $120.39 \%$ of the target drug content. Besides, it indicates that when administered to patients, daily doses may vary around $45 \%$.

The content uniformity variation observed may be explained by the increased weight variation observed after the splitting process (5), possibly due to splitter device limitations and tablet crumbing during the splitting process associated with manufacturing problems (9).

Problems related to weight and content uniformity of the split portions are reported in the literature (30-34), resulting in significant differences in the administered dose. Although all the products used in this study were scored in the middle, fragmentation along the cutting edge made the two halves uneven, resulting in increased weight and content uniformity variation. Studies have shown that even if the tablet is scored the splitting results are poorly reproducible, leading to unequal fragmentation $(1,30,33,35)$ which might cause a change in drug concentration-time profile. It is especially noted for narrow therapeutic index drugs, and loss of the active drug during the splitting process (6) which can reach up to $24 \%$ when tablets are broken in quarters, according to Biron et al. (1999) (36). Additionally, multipart fragmentation leads to the discard of active portions, as reported by Fawell et al. (1999) (12). Also, not all patients can split tablets satisfactorily, even if they are scored $(1,37)$.

The accuracy of tablet splitting will depend on individual's technique and quality of the splitting device, causing significant differences in daily use $(2,38)$. The positioning of the splitter blade directly on the tablet scoreline is not always perfect, resulting in unequal halves and consequently in weight variation in split portions (2). Therefore, some patients might have difficulties when doing it, especially the elderly population and people with reduced cognitive function, what might compromise the clinical treatment (9).

However, some authors point that small dose variations are not critical to effectiveness $(2,39)$; minor variations in a daily dose of antihypertensives, such as propranolol, should not produce a significant impact on long-term clinical treatments, but might affect blood pressure and consequently produce side effects (9).

One study performed by Rindone (2000) found no significant differences in blood pressure of patients who were administered whole and half-tablets of lisinopril (40). Other studies in which patients were administered half-tablets of statins also showed no significant clinical differences due to the splitting process (9,41-43).

Even though the tablets were scored, the resulting portions presented a high variability for both weight and drug content, which would lead patients to administer wrong doses.

The limitations of this study include the fact that only one drug was analyzed. Therefore, it cannot be representative of all medications that can be split. Furthermore, this study applied only the tablet-splitter device, perhaps other techniques such as splitting tablets with a kitchen knife or breaking them by hand would result in different variability. Additionally, we used adapted pharmacopeial criteria for assessing half-tablets weight variability and drug content uniformity to obtain the present results.

\section{CONCLUSION}

In this scenario, the unequal splitting was revealed by weight measurements and drug content test; therefore, patients would not obtain equal doses when splitting propranolol tablets, which might compromise the clinical treatment.

Clinical implications due to tablet splitting might not be critical in some cases. Nevertheless, the high variability between daily doses should be considered by healthcare professionals when prescribing a therapy involving this practice. 


\section{REFERÊNCIAS}

1. Quinzler R, Gasse C, Schneider A, Kaufmann-Kolle P, Szecsenyi J, Haefeli WE. The frequency of inappropriate tablet splitting in primary care. Eur J Clin Pharmacol. 2006; 62(12):1065-1073. DOI: 10.1007/s00228-0060202-3

2. Shah RB, Collier JS, Sayeed VA, Bryant A, Habib MJ, Khan MA. Tablet splitting of a narrow therapeutic index drug: a case with levothyroxine sodium. AAPS PharmSciTech. 2010; 11(3):1359-1367. DOI:10.1208/ s12249-010-9515-8

3. Gupta A, Hunt RL, Khan MA. Influence of tablet characteristics on weight variability and weight loss in split tablets. Am J Health Syst Pharm. 2008; 65(24):2326, 2328. DOI:10.2146/ajhp080371

4. van Vooren L, De Spiegeleer B, Thonissen T, Joye P, Van Durme J, Slegers G. Statistical analysis of tablet breakability methods. J Pharm Pharm Sci. 2002; 5(2):190-198.

5. Zhao N, Zidan A, Tawakkul M, Sayeed VA, Khan M. Tablet splitting: Product quality assessment of metoprolol succinate extended release tablets. Int J Pharm. 2010; 401(1-2):25-31. DOI: 10.1016/j.ijpharm.2010.09.004

6. van Santen E, Barends DM, Frijlink HW. Breaking of scored tablets: a review. Eur J Pharm Biopharm. 2002; 53(2):139-145.

7. Cohen JS. Ways to minimize adverse drug reactions. Individualized doses and common sense are key. Postgrad Med. 1999; 106(3):163-172. DOI: 10.3810/ pgm.1999.09.688

8. Tahaineh LM, Gharaibeh SF. Tablet splitting and weight uniformity of half-tablets of 4 medications in pharmacy practice. J Pharm Pract. 2012; 25(4):471-476. DOI: $10.1177 / 0897190012442716$

9. Hill SW, Varker AS, Karlage K, Myrdal PB. Analysis of drug content and weight uniformity for half-tablets of 6 commonly split medications. J Manag Care Pharm. 2009; 15(3):253-261. DOI: 10.18553/jmcp.2009.15.3.253

10. Cornish P. "Avoid the crush": hazards of medications administration in patients with dysphagia or a feeding tube. CMAJ. 2005; 172(7):871-872. DOI: 10.1503/ cmaj.050176

11. Carr-Lopez SM, Mallet MS, Morse T. The tablet splitter: barrier to compliance or cost-saving instrument? Am J Health-Syst Pharm. 1995; 52(23):2707-2708.

12. Fawell NG, Cookson TL, Scranton SS. Relationship between tablet splitting and compliance, drug acquisition cost, and patient acceptance. Am J Health Syst Pharm. 1999; 56(24):2542-2545.

13. Starkey E, Shahidullah H. Propranolol for infantile haemangiomas: a review. Arch Dis Child. 2011; 96(9):890-893. DOI: 10.1136/adc.2010.208884
14. Akin A, Karagöz T, Aykan HH, Özer S, Alehan D, Özkutlu $\mathrm{S}$. The efficacy of amiodarone-propranolol combination for the management of childhood arrhythmias. Pacing Clin Electrophysiol. 2013; 36(6):727-731. DOI: 10.1111/ pace. 12107

15. Salazar-Murillo R, García-Pacheco S, González-Blanco MJ, Bolívar-Montesa P, Campos-García S. Propranolol: Treatment of capillary hemangioma with orbital involvement. Arch Soc Esp Oftalmol. 2012; 87(12):411414. DOI: 10.1016/j.oftal.2011.07.017

16. Chung SJ, Kwon H, Lee DK, Hong JY, Sunwoo MK, Sohn YH, Lee JM, Lee PH. Neuroanatomical heterogeneity of essential tremor according to propranolol response. PLoS One. 2013. 8(12):e84054. DOI: 10.1371/journal. pone. 0084054

17. Galletti F, Cupini LM, Corbelli I, Calabresi P, Sarchielli P. Pathophysiological basis of migraine prophylaxis. Progress in Neurobiology. 2009; 89(2):176-192. DOI: 10.1016/j.pneurobio.2009.07.005

18. Micromedex 2.0. Micromedex Gateway. [citado $25 \mathrm{fev}$ 2017]. Disponível em: http://www.micromedexsolutions. com/micromedex2/librarian/

19. Fette A. Propranolol in use for treatment of complex infant hemangiomas: literature review regarding current guidelines for preassessment and standards of care before initiation of therapy. Scientific World J. 2013; 2013:850193. DOI: $10.1155 / 2013 / 850193$

20. Finnerty CC, Herndon DN. Is propranolol of benefit in pediatric burn patients? Adv Surg. 2013; 47:177-197.

21. Poundja J, Sanche S, Tremblay J, Brunet A.Trauma reactivation under the influence of propranolol: an examination of clinical predictors. Eur J Psychotraumatol. 2012; 3:15470. DOI: 10.3402/ejpt.v3i0.15470.

22. BRASIL. Farmacopeia Brasileira. 5 edição, Vol. 1. Agência Nacional de Vigilância Sanitária. Brasília: Anvisa, 2010.

23. USP. United States Pharmacopeial Convention. United States Pharmacopeia and National Formulary, USP39NF34. Rockville, MD: United States Pharmacopeial Convention, Inc.; 2016.

24. Rosenberg JM, Nathan JP, Plakogiannis F. Weight variability of pharmacist dispensed split tablets. J Am Pharm Assoc (Wash). 2002; 42(2):200-205.

25. Elliott I, Mayxay M, Yeuichaixong S, Lee SJ, Newton PN. The practice and clinical implications of tablet splitting in international health. Trop Med Int Health. 2014; 19(7):754-760. DOI: 10.1111/tmi.12309

26. Habib WA, Alanizi AS, Abdelhamid MM, Alanizi FK. Accuracy of tablet splitting: Comparison study between hand splitting and tablet cutter. Saudi Pharm J. 2014; 22(5):454-459. DOI: 10.1016/j.jsps.2013.12.014 
27. Helmy SA. Tablet splitting: is it worthwhile? Analysis of drug content and weight uniformity for half tablets of 16 commonly used medications in the outpatient setting. J Manag Care Spec Pharm. 2015; 21(1):76-86. DOI: 10.18553/jmcp.2015.21.1.76

28. FDA. Food and Drug Administration. Guidance for Industry Tablet Scoring: Nomenclature, Labeling, and Data for Evaluation, March 2013 [on-line]. Available at: http://www.fda.gov/downloads/Drugs/ GuidanceComplianceRegulatoryInformation/Guidances/ UCM269921.pdf

29. van der Steen KC, Frijlink HW, Schipper CM, Barends DM. Prediction of the ease of subdivision of scored tablets from their physical parameters. AAPS PharmSciTech. 2010; 11(1):126-132. DOI: 10.1208/s12249-009-9365-4

30. Polli JE, Kim S, Martin BR. Weight uniformity of split tablets required by a Veterans Affairs policy. J Manag Care Pharm. 2003; 9(5):401-407. DOI: 10.18553/ jmcp.2003.9.5.401

31. Zaid AN, Al-Ramahi RJ, Ghoush AA, Qaddumi A, Zaaror YA. Weight and content uniformity of lorazepam half-tablets: A study of correlation of a low drug content product. Saudi Pharm J. 2013; 21(1):71-75. DOI: 10.1016/j.jsps.2011.12.009

32. Kristensen HG, Jorgensen GH, Moller-Sonnergaard JJ. Mass uniformity of tablets broken by hand. Pharmeuropa. 1995; 7:298-302.

33. Cook TJ, Edwards S, Gyemah C, Shah M, Shah I, Fox T. Variability in tablet fragment weights when splitting unscored cyclobenzaprine $10 \mathrm{mg}$ tablets. J Am Pharm Assoc. 2004; 44(5):583-586.

34. Teng J, Song CK, Williams RL, Polli JE. Lack of medication dose uniformity in commonly split tablets. J Am Pharm Assoc (Wash). 2002; 42(2):195-199.
35. Rodenhuis N, De Smet PA, Barends DM. The rationale of scored tablets as dosage form. Eur J Pharm Sci. 2004; 21(2-3):305-308.

36. Biron C, Licznar S, Hansel S, Schved JF. Oral anticoagulant drugs: do not cut tablets in quarters. Thromb Haemost. 1999; 82(3):1201.

37. Atkin PA, Finnegan TP, Ogle SJ, Shenfield GM. Functional ability of patients to manage medication packaging: a survey of geriatric inpatients. Age Ageing. 1994; 23(2):113-116.

38. Sales MM, Cunningham FE. Tablet splitting. TIPS NCPS VA National Center for Patients Safety. 2006; 6(3):1-5.

39. Cohen C, Cohen S. Potential savings from splitting newer antidepressant medications. CNS Drugs. 2002; 16:353-358.

40. Rindone JP. Evaluation of tablet-splitting in patients taking lisinopril for hypertension. J Clin Outcomes Manage. 2000; 7(4):22-24.

41. Duncan MC, Castle SS, Streetman DS. Effect of tablet splitting on serum cholesterol concentrations. Ann Pharmacother. 2002; 36(2):205-209. DOI: 10.1345/ aph.1A233

42. Gee M, Hasson NK, Hahn T, Ryono R. Effects of a tabletsplitting program in patients taking HMG-CoA reductase inhibitors: analysis of clinical effects, patient satisfaction, compliance, and cost avoidance. J Manag Care Pharm. 2002; 8(6):453-458. DOI: 10.18553/jmcp.2002.8.6.453

43. Parra D, Beckey NP, Raval HS, Schnacky KR, Calabrese V, Coakley RW, Goodhope RC, Veterans Integrated Service Network 8 Pharmacy Benefits Management Utilization Committee. Effect of splitting simvastatin tablets for control of low-density lipoprotein cholesterol. Am J Cardiol. 2005; 95(12):1481-1483 